\title{
Down-regulation of UBC9 increases the sensitivity of hepatocellular carcinoma to doxorubicin
}

\author{
Sufen Fang ${ }^{2, *}$, Junyao Qiü, ${ }^{2,}$, Zheng $\mathbf{W u}^{2}$, Tao Bai ${ }^{2}$ and Wuhua Guo ${ }^{1}$ \\ ${ }^{1}$ Department of Interventional Radiology, Mengchao Hepatobiliary Hospital of Fujian Medical University, Fuzhou 350025, China \\ ${ }^{2}$ Department of Gastroenterology, The Second Affiliated Hospital of Nanchang University, Nanchang 330006, China \\ *These authors have contributed equally to this work
}

Correspondence to: Wuhua Guo, email: guowuhua@aliyun.com

Keywords: UBC9, SUMOylation, hepatocellular carcinoma (HCC), doxorubicin (DOX), apoptosis

Received: December 20, $2016 \quad$ Accepted: May 05, $2017 \quad$ Published: May 17, 2017

Copyright: Fang et al. This is an open-access article distributed under the terms of the Creative Commons Attribution License 3.0 (CC BY 3.0), which permits unrestricted use, distribution, and reproduction in any medium, provided the original author and source are credited.

\section{ABSTRACT}

UBC9 is an E2-conjugating enzyme that is required for SUMOylation and has been implicated in regulating several critical cellular pathways. UBC9 is overexpressed in certain tumors, such as lung adenocarcinoma, ovarian carcinoma and melanoma, which implies that it has special clinical significance. However, the role of UBC9 in Hepatocellular carcinoma (HCC) drug responsiveness is not clear. In this study, we investigated the clinicopathological significance of UBC9 in HCC and investigated the mechanism of UBC9-mediated chemosensitivity to doxorubicin (DOX) in hepatocellular carcinoma cells. We found that relative to adjacent normal tissues, UBC9 was markedly overexpressed in HCC, which closely correlated with tumor size, tumor microsatellite formation, and tumor encapsulation. Our results also showed that down-regulation of UBC9 by shRNA reduced the expression of $\mathrm{Bcl}-2$ and $\mathrm{Bcl}-\mathrm{xl}$ and increased the expression of cleaved-Caspase3, which is a proapoptotic protein. These changes were associated with reduced apoptosis in response to DOX. Furthermore, we observed a mechanism involving modulation of the P38 and ERK1/2 signaling pathways. Together, our results indicate that down-regulation of UBC9 sensitizes cells to anticancer drugs, is possibly associated with the regulation of ERK1/2 and P38 activation and interacts with the intrinsic apoptosis pathway. Thus, knockdown of UBC9 may have a tumor suppressor effect and UBC9 could be a potential target for the treatment of HCC cancer.

\section{INTRODUCTION}

Hepatocellular carcinoma (HCC) is the fifth mostcommon cancer and the second leading cause of cancerrelated deaths worldwide [1]. However, in China in 2015, it was estimated that 111.5 thousand people died from HCC, which was the third leading cause of cancer-related deaths in China [2]. Due to its hidden onset, clinical diagnosis of hepatocellular carcinoma is more complex and there are few effective treatments. The effective treatments for HCC include surgery, intervention therapy and molecular target therapy, among a few other options [3]. Molecular target therapy is currently the primary focus of drug and treatment development for HCC [4], and this approach has led to breakthroughs in effective treatments for malignant tumors."However, sorafenib, the sole medicine that targets HCC, can only increase the average survival rate of patients by approximately 3 months [4-6], and sorafenib has side effects, such as diarrhea, handfoot skin disease, and high blood pressure [7, 8].The poor efficacy and severe side effects seriously limit the use of sorafenib in clinical practice [9]. Therefore, new molecular target drugs with better efficacy and lower side effects should be studied further to develop additional treatments for HCC.

SUMO is a highly conserved protein family that is involved in protein modification after translation. Although SUMOylation is similar to ubiquitination in 
structure, conjugation process and attachment to target proteins, their biological consequences are different. Unlike ubiquitination, which normally targets protein degradation, SUMOylation has been implicated in the regulation of protein stability, protein-protein interactions, transcriptional activity and subcellular localization [10-11]. SUMOylation is a multi-step process that is catalyzed by multiple enzymes, including the E1, E2 and E3 enzymes [10-11]. In contrast to the ubiquitination pathway, which utilizes several E2 conjugating enzymes [12], UBC9 is the only known E2 conjugating enzyme in the SUMO pathway and has been found in yeast, invertebrates and vertebrates [13-15].SUMOylation regulates a diverse array of cellular functions, including DNA replication and repair, chromosome integrity and segregation, kinetochore assembly, nuclear transport, signal transduction and cell cycle progression [16-21]. Many proto-oncogenic and tumor suppressor proteins are targets of SUMOylation, including Bc12, PLAG1/ PLAGL2, c-Fos, c-Myb and c-Jun, which plays a key role in regulating cancer cell proliferation and survival [20]. Some oncogenic signaling pathways were found to be regulated by SUMOylation, including MAPK, $\mathrm{NF}-\kappa \mathrm{B}$, nuclear receptor transcription factors and their coregulators [22-24].

As the sole E2 enzyme, UBC9 is believed to play a central role in the biological processes of cell development through SUMOylation. UBC9 plays a crucial role in cell cycle regulation, apoptosis, DNA repair, gene transcription and nucleocytoplasmic transport [25, 26]. Other more recent studies have shown that UBC9 can function without depending on SUMOylation to regulate cell growth $[27,28]$. These studies suggested that regulating the expression of UBC9 would lead to changes in cell growth and function. In support of this notion, it was reported that UBC9 might regulate bcl-2 expression through the ER signaling pathway, which ultimately contributes to alterations in drug responsiveness and tumor growth [30]. It also has previously been shown that overexpression of UBC9-DN is associated with increased drug sensitivity in breast cancer [32]. In yeast, a defect in the ubc9 gene caused increased sensitivity to genotoxic drugs [33]. Therefore, the influence of the expression or function of UBC9 can impact drug responsiveness and tumorigenesis and alterations in protein SUMOylation and de-SUMOylation caused by UBC9 could affect cancer development and drug resistance.

Given the importance of UBC9 in tumor development and growth, we first demonstratedin this study that UBC9 was upregulated in HCC tissues compared to non-tumor tissues and showed that overexpression of UBC9 was associated with tumor aggressiveness and the grade of malignancy. We also studied whether down-regulated expression of UBC9 could increase the sensitivity of HCC cells to chemotherapy drugs. As shown in prior studies, doxorubicin (DOX) is widely used in HCC chemotherapy and mainly functions by preventing DNA replication and RNA synthesis, which ultimately inhibits tumor cell division and proliferation [34]. In this study, we aimed to determine if inhibition of UBC9 expression could increase the sensitivity of HCC cells to DOX and to examine the molecular mechanisms that were involved.

\section{RESULTS}

\section{To explore the expression and significance of UBC9 in hepatic cancer (HCC) tissues}

The expression levels of UBC9 were determined for 103 patients with hepatic cancer by immunohistochemistry and Western blot. The results of immunohistochemistry and Western blot showed that the expression of UBC9 was significantly higher compared to that of the adjacent pericancerous liver tissues. The IHC results showed that the UBC9 protein was highly expressed in $69.92 \%$ $(72 / 103)$ of the HCC tissue samples and in only $17.47 \%$ $(18 / 103)$ of the adjacent tissues (Figure 1C). Additionally, the western blotting results showed that the UBC9 protein levels were significantly elevated in HCC tissues (Figure 1A and 1B), which was consistent with the IHC results. These findings strongly indicate that UBC9 was overexpressed in HCC. The difference was statistically significant $(P<0.001)$. Next, we analyzed the association between UBC9 expression and the clinical pathological parameters in $103 \mathrm{HCC}$ patients. The results showed that UBC9 overexpression correlated closely with tumor size, tumor microsatellite formation, and tumor encapsulation $(P<0.05$ for all; Table 1$)$. These results indicated that UBC9 overexpression was involved in HCC aggressiveness and the grade of malignancy. Additional experiments were needed to determine whether the status of UBC9 overexpression might be an independent factor.

\section{Analysis of UBC9 expression with UBC9 shRNA in $\mathrm{HCC}$ cells}

We first examined the levels of UBC9 in a variety of HCC cells by Western blotting. The results indicated that the expression of UBC9 in HCC cells was higher than that in normal liver cells (Figure 2A). Then, we stably transfected a UBC9-specific short hairpin RNA (shUBC9) into in HepG2 and SMMC-7721 cells, which exhibit relatively high expression of UBC9 among HCC cell lines (Figure 2A). Western blotting and qRT-PCR showed that the UBC9 levels significantly declined in HepG2 cells (Figure 2B-2D). The amounts of UBC9 mRNA and protein were significantly reduced in $\mathrm{HepG} 2$ cells transfected with one UBC9 shRNA (shUBC9-a), which showed that efficient knockdown of UBC9 occurred. Similar results were observed in cells transfected with another UBC9 shRNA (shUBC9-b), although the effect of UBC9 downregulation was smaller. However, the 
UBC9 expression levels were only slightly affected by the transfection of UBC9 shRNA (shUBC9-c). The amounts of UBC9 protein were significantly reduced in SMMC7721 cells transfected with one UBC9 shRNA (shUBC9-a) (Figure 2E and 2F), These results suggested that UBC9 shRNA could substantially reduce UBC9 expressions in HCC cells though transfection of UBC9-a shRNA.

\section{The influence on proliferation after transfection of UBC9 shRNA in combination with doxorubicin treatment in $\mathrm{HCC}$ cells}

To address the role of UBC9 in chemosensitivity of HCC cells, HCC cells were transfected with UBC9shRNA or NC-shRNA.The G418-resistant mix clones were selected for further experiments. Then the cells were treated with different concentrations of DOX $(0,0$ $-1.6 \mu \mathrm{g}$ for $24 \mathrm{~h}$. The cell viability in the presence of DOX was further evaluated with CCK8 assay. It was indicated down-regulation of UBC9 resulted in poor cell viability (Figure 3B). The IC50 values of HCC cells to DOX were calculated from the cell viability plots. For hepG2 cells, IC50 values of shUBC9-a group cells were decreased compared to NC group $(p<0.05)$; but there was no significant difference between the Normal and shNC group cells (Figure 3A), For SMMC-7721, As displayed by Figure 3C, suppression of UBC9 was also accompanied by significantly decreased IC50 values. These data all indicated that down-regulation of UBC9 could increase sensitivity of HCC cells to DOX.

To study the inhibition rate of DOX in HCC cells, we used the three groups of HepG2 and SMMC7721

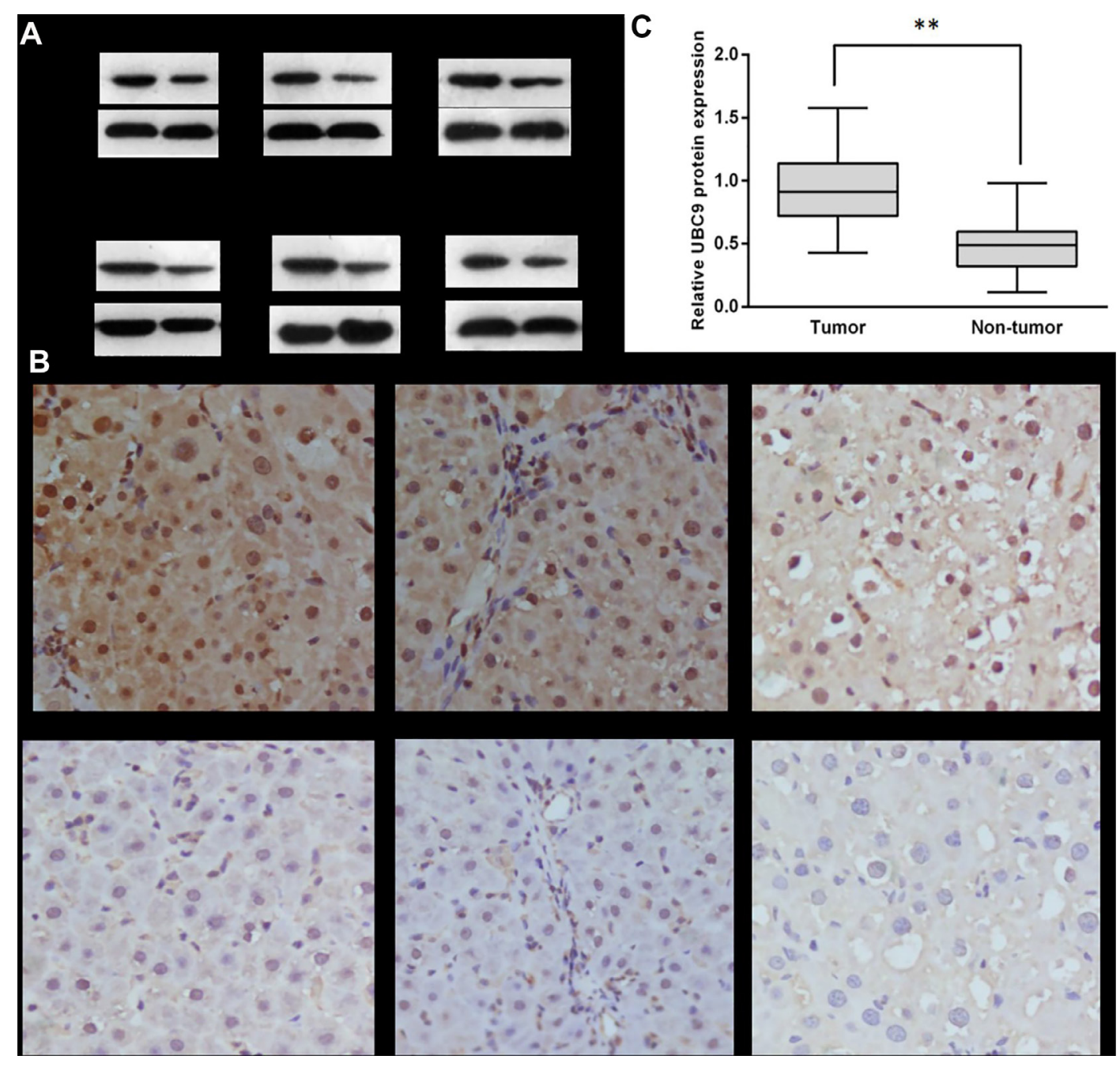

Figure 1: The expression of UBC9 in human HCC tumors and adjacent non-tumor liver tissues. (A) Representative Western blot analysis of UBC9 protein expression (T: tumor, NT: non-tumor tissues). (B) Quantification of UBC9 protein expression using Western blot analyses for 103 paired HCC and their adjacent non-tumor tissues. GAPDH protein expression was used as an internal control $(* * P<0.001)$. (C) Strong cytoplasmic and nuclear expression of UBC9 protein in 26th carcinoma tissues (a distant metastasis case); moderate cytoplasmic and nuclear expression of UBC9 protein in 56th carcinoma tissues (an intrahepatic metastasis case); weak cytoplasmic and nuclear expression of UBC9 protein in 85th carcinoma tissues (a case with small tumors and no transfer); almost no expression of UBC9 protein was seen in the adjacent non-tumor tissues. 
Table 1: The $P$ values represent probabilities for UBC9 expression levels between variable subgroups determined by the $\chi 2$ test

\begin{tabular}{|c|c|c|c|c|}
\hline \multirow[b]{2}{*}{ Pathologic Characteristics } & \multirow[b]{2}{*}{$N$} & \multicolumn{2}{|c|}{ UBC9 } & \multirow[b]{2}{*}{$P$ value } \\
\hline & & $\begin{array}{l}\text { Overexpression } \\
\text { (number of cases) }\end{array}$ & $\begin{array}{l}\text { Nonoverexpression } \\
\text { (number of cases) }\end{array}$ & \\
\hline \multicolumn{5}{|l|}{ Age, years } \\
\hline$\leq 60$ & 69 & 46 & 23 & 0.095 \\
\hline$>60$ & 34 & 26 & 8 & \\
\hline \multicolumn{5}{|l|}{ Sex } \\
\hline Male & 86 & 68 & 18 & 0.239 \\
\hline Female & 17 & 8 & 9 & \\
\hline \multicolumn{5}{|l|}{ Tumor size (cm) } \\
\hline$\leq 5$ & 45 & 26 & 19 & 0.001 \\
\hline$>5$ & 58 & 46 & 12 & \\
\hline \multicolumn{5}{|c|}{ Tumor microsatellite formation } \\
\hline Absent & 66 & 37 & 29 & $<0.001$ \\
\hline Present & 37 & 35 & 2 & \\
\hline \multicolumn{5}{|l|}{ HBsAg } \\
\hline Negative & 13 & 11 & 2 & 0.216 \\
\hline Positive & 90 & 61 & 29 & \\
\hline \multicolumn{5}{|l|}{$\operatorname{AFP}(\mathrm{ng} / \mathrm{ml})$} \\
\hline$\leq 400$ & 51 & 36 & 15 & 0.914 \\
\hline$>400$ & 52 & 36 & 16 & \\
\hline \multicolumn{5}{|l|}{ Cirrhosis } \\
\hline Absent & 39 & 26 & 13 & 0.576 \\
\hline Present & 64 & 46 & 18 & \\
\hline \multicolumn{5}{|l|}{ Tumor encapsulation } \\
\hline Absent & 15 & 5 & 10 & 0.001 \\
\hline Present & 88 & 67 & 21 & \\
\hline \multicolumn{5}{|c|}{ Portal vein tumor thrombosis } \\
\hline Absent & 93 & 64 & 29 & 0.546 \\
\hline Present & 10 & 8 & 2 & \\
\hline
\end{tabular}

Abbreviations: AFP, a-fetoprotein; HBsAg, hepatitis B surface antigen.

cells respectively transfected with $0,0.3,0.6$ and $0,0.2$, $0.4 \mu \mathrm{g} / \mathrm{ml} \mathrm{DOX}$ for $24 \mathrm{~h}$ to assess the cell viability by CCK8 assays. The shUBC9-a group combined with doxorubicin treatment had a significantly increased inhibition rate $(P<0.01)$ compared to shNC group cells treated with doxorubicin. (Figure 3B, 3D)

\section{The influence of the apoptosis associated protein expression after UBC9 shRNA was combined with DOX treatment in $\mathrm{HCC}$ cells}

we manipulated the apoptosis associated protein levels by the stable transfection of UBC9shRNA or vector control into HepG2 and SMMC-7721 cells.Western blotting showed that the knockdown of UBC9 reduced the expression of $\mathrm{Bcl}-2$ and $\mathrm{Bcl}-\mathrm{xl}$ and increased the expression of cleaved-Caspase3 in HepG2 and SMMC7721 cells (Figure 4A-4D). The Ct values of the Bcl-2, Bcl$\mathrm{xl}$ and $\mathrm{UBC} 9$ protein were significantly decreased in the shUBC9-a and shUBC9-a with DOX groups $(P<0.001)$, and the shUBC9-a with DOX group had a greater reduction compared to shUBC9 $(P<0.001)$. The $\mathrm{Ct}$ values of the cleaved-Caspase 3 protein were significantly increased in the shUBC9-a and shUBC9-a with DOX groups $(P<0.001)$, and the shUBC9-a with DOX group had a greater increased compared to the shUBC9 group $(P<0.001)$. 

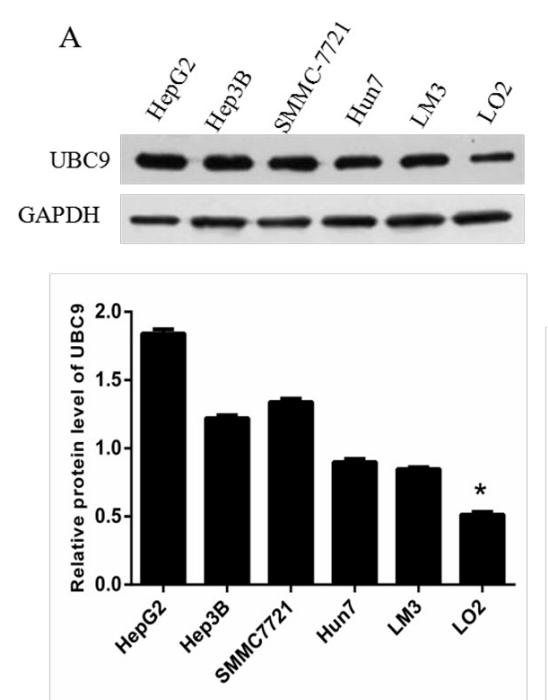

C

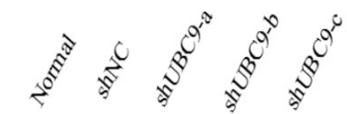

GAPDH

B

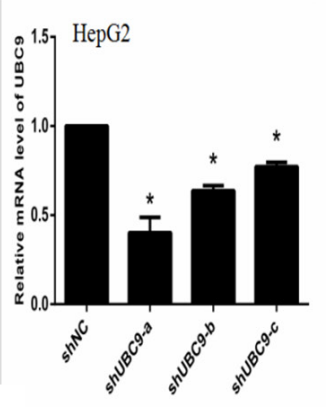

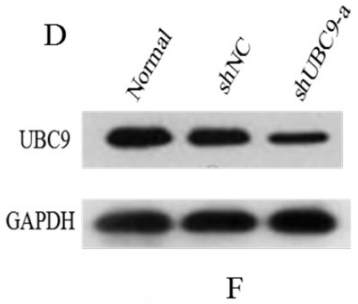

F

Figure 2: UBC9 expression in untreated and treated groups of HCC cells. (A) Western blot analyses of UBC9 expression in the indicated HCC cell lines and the normal liver cell line LO2. ${ }^{*} P<0.001 \mathrm{vs.} \mathrm{Each} \mathrm{hepatoma} \mathrm{cell} \mathrm{lines.} \mathrm{(B)} \mathrm{The} \mathrm{mRNA} \mathrm{expressions} \mathrm{of} \mathrm{UBC9}$ in HepG2 cells with UBC9-shRNA were determined by qRT-PCR. $* P<0.01$ vs NC shRNA transected cells. (C and $\mathbf{D})$ Protein expression of UBC9 was examined using Western blots in HepG2 and SMMC-7721 cells. ${ }^{*} P<0.001$ vs NC shRNA transected cells. (E and F) Graph of the relative ratios of UBC9 protein to GAPDH in each group. ${ }^{*} P<0.001 \mathrm{vs.NC}$ shRNA transected cells.

$\mathrm{C}$

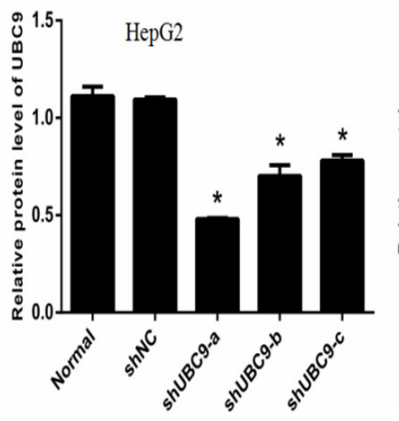

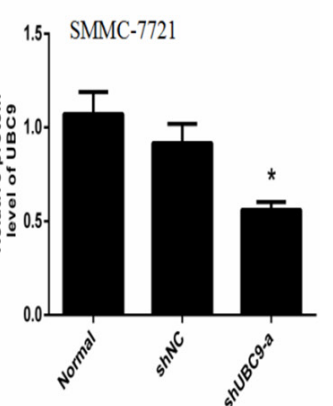

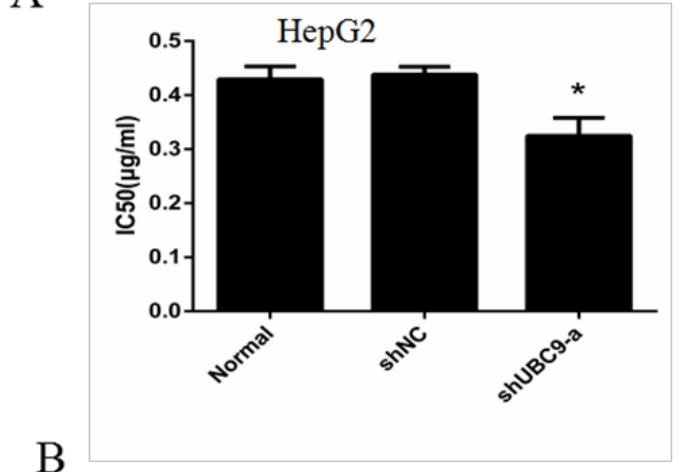

B

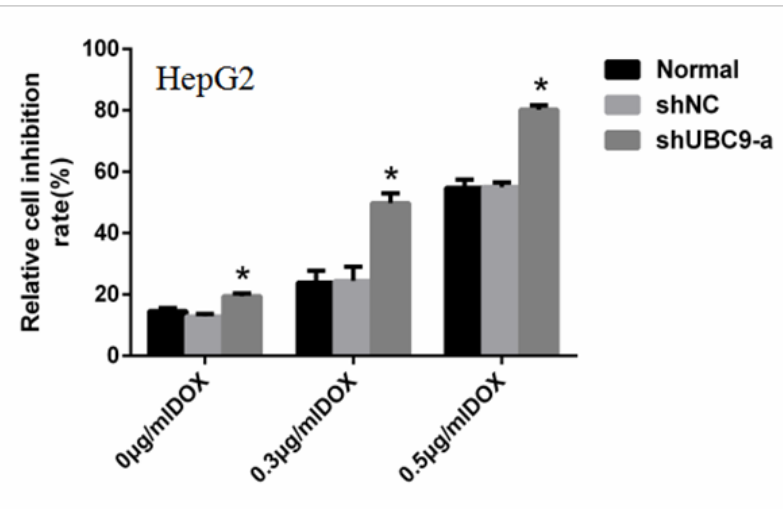

$\mathrm{D}$
A

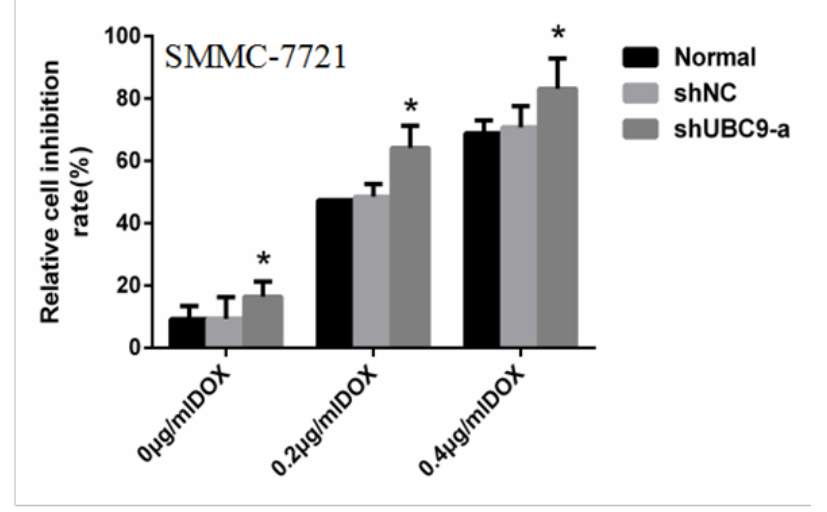

Figure 3: Down-regulation of UBC9 sensitized HCC cells to Doxorubicin. (A and C) The IC50 values of HepG2 and SMMC7721 cellswere determined according to the plot. ${ }^{*} p<0.01$ vs NC shRNA transfected cells, $n=3$. (B and D) The viability was measured by CCK8. The cell viability experiments revealed that treatment of HepG2 and SMMC-7721 cells with UBC9-shRNA resulted in more enhanced sensitivity to doxorubicin in comparison to Normal cells and NC shRNA transfected cells. The values are mean \pm standard deviation. ${ }^{*} P<0.001$ vs NC shRNA transfected cells. 


\section{The influence of apoptosis after UBC9 shRNA in combination with DOX treatment in HCC cells}

We investigated whether the effects of shUBC9-a with DOX treatment increased apoptosis using the Annexin V-FITC/PI staining method. We used three groups of cells alone or treated with doxorubicin for 24 h. UBC9 knockdown or DOX treatment led to a marked increase in cell apoptosis; however, combination of UBC9 knockdown with DOX induced a higher cell apoptosis than chemotherapy group alone in HepG2 and SMMC7721 (Figure 5A-5C). These findings suggested that down-regulation of UBC9 expression increased the chemosensitivity of doxorubicin-treated $\mathrm{HCC}$ cells by inducing apoptosis.

\section{The effects on cell cycle progression after UBC9 shRNA combined with DOX Treatment in HCC cells}

To examine whether UBC9 shRNA combined with DOX was related to the cell cycle, we examined cell cycle progression using flow cytometry. We used three groups of cells alone or cells treated with doxorubicin for
$48 \mathrm{~h}$. The cell cycle assay revealed that the shUBC9-a group had a higher number of cells in the $\mathrm{G} 2 / \mathrm{M}$ phase compared to the Normal and shNC groups $(p<0.01)$ (Figure 6A-6C). Moreover, the cells shUBC9-a combined with DOX treatment caused more accumulation of cells in the G2/M phase compared to the other groups $(P<0.001)$. The increase in the $\mathrm{G} 2 / \mathrm{M}$ phase cell population was accompanied by a reduction in the number of cells in the G0/G1 and S phases of the cell cycle. Therefore, UBC9 shRNA combined with DOX induced cell cycle arrest at the $\mathrm{G} 2 / \mathrm{M}$ phase.

\section{The effects on the MAPK signal pathway after UBC9 shRNA was combined with DOX treatment in $\mathrm{HCC}$ cells}

Cell apoptosis is tightly controlled by a complex regulatory network. The MAPK pathway is required for apoptosis and can be induced by chemotherapeutic agents, and when UBC9 shRNA was combined with DOX, the MAPK pathways may play a key role in the induction of apoptosis. The expression of the p-p38 and p-ERK1/2 proteins obviously decreased in the shUBC9-a with DOX and shUBC9-a groups $(P<0.001$ all $)$ in HepG2 and

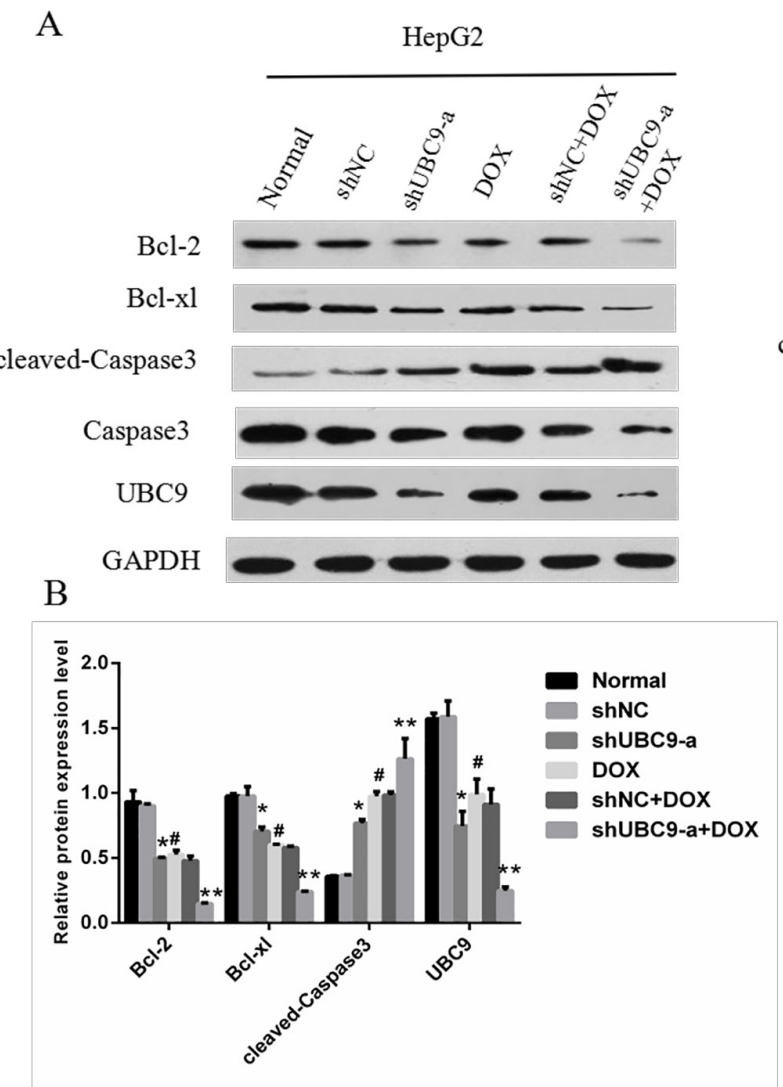

$\mathrm{C}$

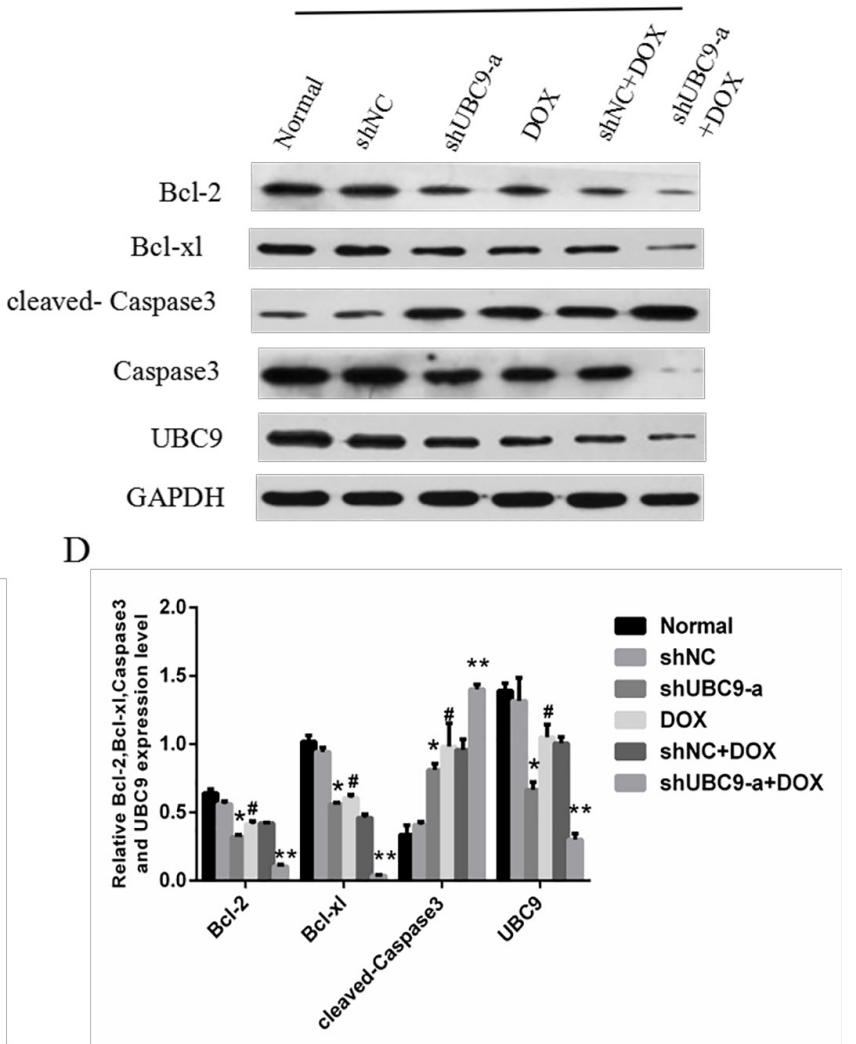

Figure 4: The effect of UBC9 on apoptosis-related proteins in HCC cells. (A and $\mathbf{C}$ ) The expression of cleaved-Caspase3, Caspase3,Bcl-2, UBC9 and Bcl-xl in HepG2 and SMMC-7721 cells were evaluated by Western blot. (B and D) Graph of the relative ratios of cleaved-Caspase3,Bcl-2, UBC9 and Bcl-xl protein to GAPDH in each group. ${ }^{*} P<0.05$ compared to shNC cells without DOX, ${ }^{* *} P<0.001$ compared to shNC cells with DOX. ${ }^{*} P<0.001$ vs Normal cells without DOX, $n=6$. 
SMMC-7721 cells, and the shUBC9-a with DOX group had a larger reduction compared to shUBC9-a alone $(P<0.001)$ (Figure 7A, 7B).

\section{DISCUSSION}

Protein SUMOylation has been implicated in the regulation of protein stability, subcellular localization, and activity of transcription factors [35-37]. There is also evidence that suggests that SUMOylation alterations are associated with multidrug resistance in hepatocellular carcinoma [38]. UBC9 is the sole E2-conjugating enzyme required for SUMOylation. Therefore, inhibiting the expression of UBC9 could damage cell SUMOylation. There is increasing evidence that UBC9 plays an important role in human neoplasia [39-41] and in chemotherapy resistance,which has been demonstrated both in nonsmall-cell lung cancer and melanomas [42-43]. Recently, another study has indicated that high UBC9 expression correlates with a poor response to chemotherapy and poor clinical prognosis in breast cancer [44]. Given these findings, we know that UBC9 may have a global function in tumorigenesis and drug responsiveness.
In the present study, we investigated the effects of the down-regulation of UBC9 on chemosensitivity to doxorubicin in HCC cells and explored the underlying mechanisms. First, our data indicated that UBC9 was upregulated in HCC tissues and cells. UBC9 overexpression correlated closely with tumor size, tumor microsatellite formation, and tumor encapsulation. Second, down-regulation of UBC9 increased DOXinduced apoptosis and caused cell-cycle arrest in HCC cells. Third, inhibition of UBC9 significantly lowered the IC50 values of DOX for HCC cells, which indicated that down-regulation of UBC9 increased the sensitivity of HCC cells to DOX. Fourth, down-regulation of UBC9 resulted in a decrease in the expression of the antiapoptotic proteins Bcl-2 and Bcl-xl as well as upregulation of the expression of the pro-apoptotic proteins cleavedCaspase 3 in HCC cells, which are important regulators of apoptosis and drug resistance [45]. Finally, the results indicate that knockdown of UBC9 may have an effect on the MAPK signaling pathway, which has an important role in both cell apoptosis and tumor cell drug resistance [46].

The extrinsic death receptor and intrinsic mitochondrial pathway can both induce death in cancer
A

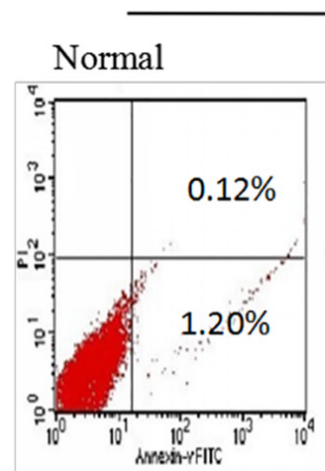

$$
\text { DOX }
$$

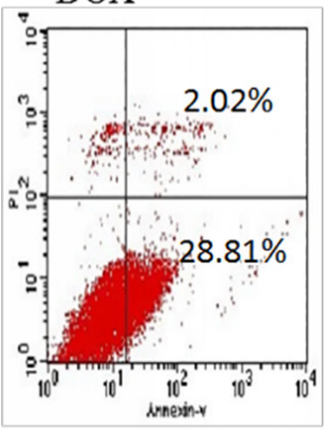

HepG2
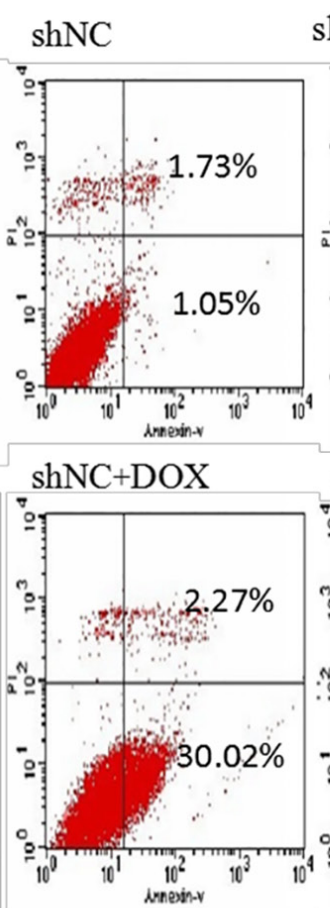

shUBC9-a
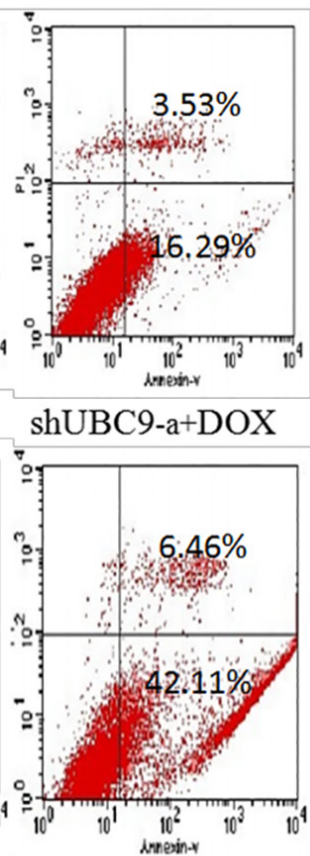

B

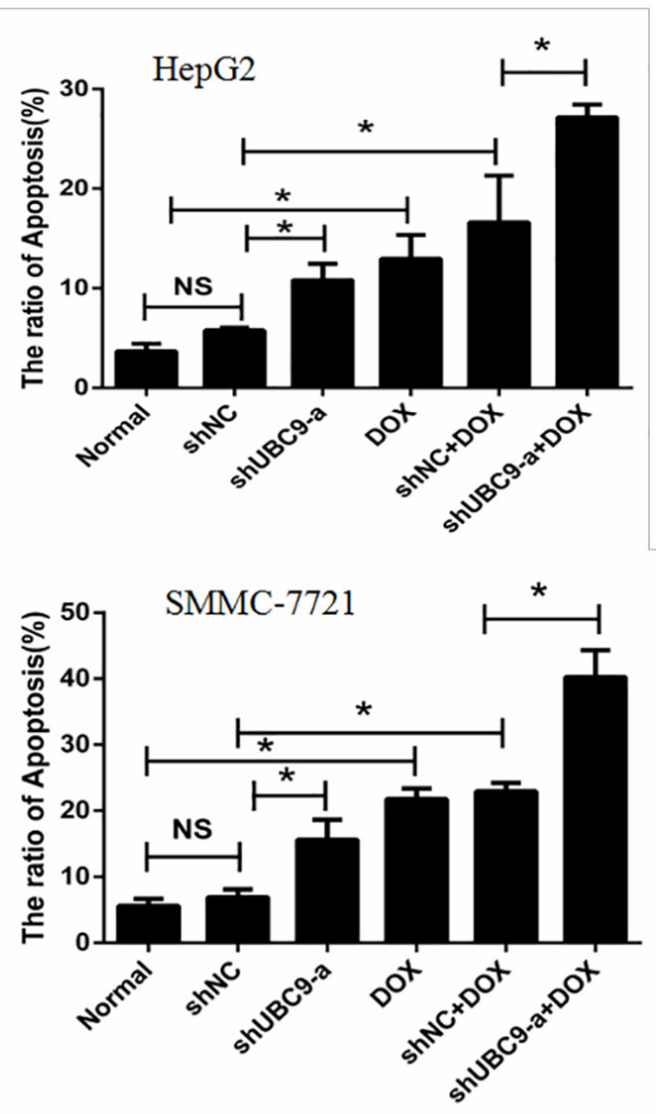

Figure 5: Down-regulation of UBC9 enhanced DOX-induced apoptosis in HCC cells. (A) Cell apoptosis was analyzed with flow cytometry, and the percentage of apoptotic cells was determined according to cells expressing Annexin. (B and C) Early and late apoptotic cells were increased in UBC9 shRNA in combination with DOX compared to other group cells. ${ }^{*} P<0.001$ vs NC shRNA transfected cells $n=6$. 
cells and sensitize them to established cytotoxic agents and radiation therapy [47]. In the present study, downregulation of UBC9 significantly suppressed expression of Bcl-2 and Bcl-xl in addition to promoting expression of cleaved-Caspase 3 combined with DOX. These data suggest that UBC9 modulates DOX-induced apoptosis via the intrinsic apoptosis pathway. Recently, drug resistance has been attributed to abrogation of the intrinsic apoptosis pathway [47]. Bcl-2, one of the most important regulators of this pathway is part of the Bcl-2 family of proteins, and upregulation of $\mathrm{Bcl}-2$ expression increases resistance to chemotherapeutic drugs, whereas downregulation of Bcl-2 expression promotes an apoptotic response to anticancer drugs [45]. Additionally,chemotherapy drugs, such as doxorubicin, can lead to unnecessary cell death, whereas Bcl-xl showed a stronger protective effect than Bcl-2 against cell death induced by several chemotherapy agents [48]. In particular, Caspase 3 is one of the key components of apoptosis and is responsible for the Bcl-2and Bcl$\mathrm{xl}$ proteins [49]. Thus, the findings suggest that downregulation of UBC9 significantly increased the sensitivity to DOX and that sensitivity might be partly activated by the intrinsic apoptotic pathway in HCC cells.

It was reported that SUMOylation plays an important role in MAPK signal pathway conditioning
[50-52]. MAPK is an important component of cell signaling pathways and regulates many protein functions in human cells [53]. The MAPK pathways respond to various extracellular stimuli and control a large number of fundamental cellular processes, including growth, proliferation, differentiation, survival and apoptosis [54]. Mitogen-activated protein kinase (MAPK) play an important role in both cell apoptosis and tumor cell drug resistance [45]. MAPKs include extracellular signal-regulated kinase (ERK), p38, and c-Jun NH2terminal kinase (JNK) [55]. The ERK-MAPK signaling pathways are closely related to cell drug susceptibility [56], and there is also a recognized connection between the MAPK and intrinsic apoptosis pathways. Activation of ERK1/2 inhibits BIM-induced apoptosis by interfering with the binding of BIM to MCL-1 and BCL-XL [57]. The P38-MAPK signaling pathways are closely related to stress-induced apoptosis and cell-drug susceptibility [58]. Our study showed that down-regulation of UBC9 combined with DOX inhibited ERK1/2 and P-p38 activation in HepG2 and SMMC-7721 cells. The levels of phosphorylation of ERK and P38 expression decreased in HCC, which indicated that inhibition of UBC9 increased the sensitivity of chemotherapeutic drugs through inhibition of the ERK1/2-MAPK and P38-MAPK cell

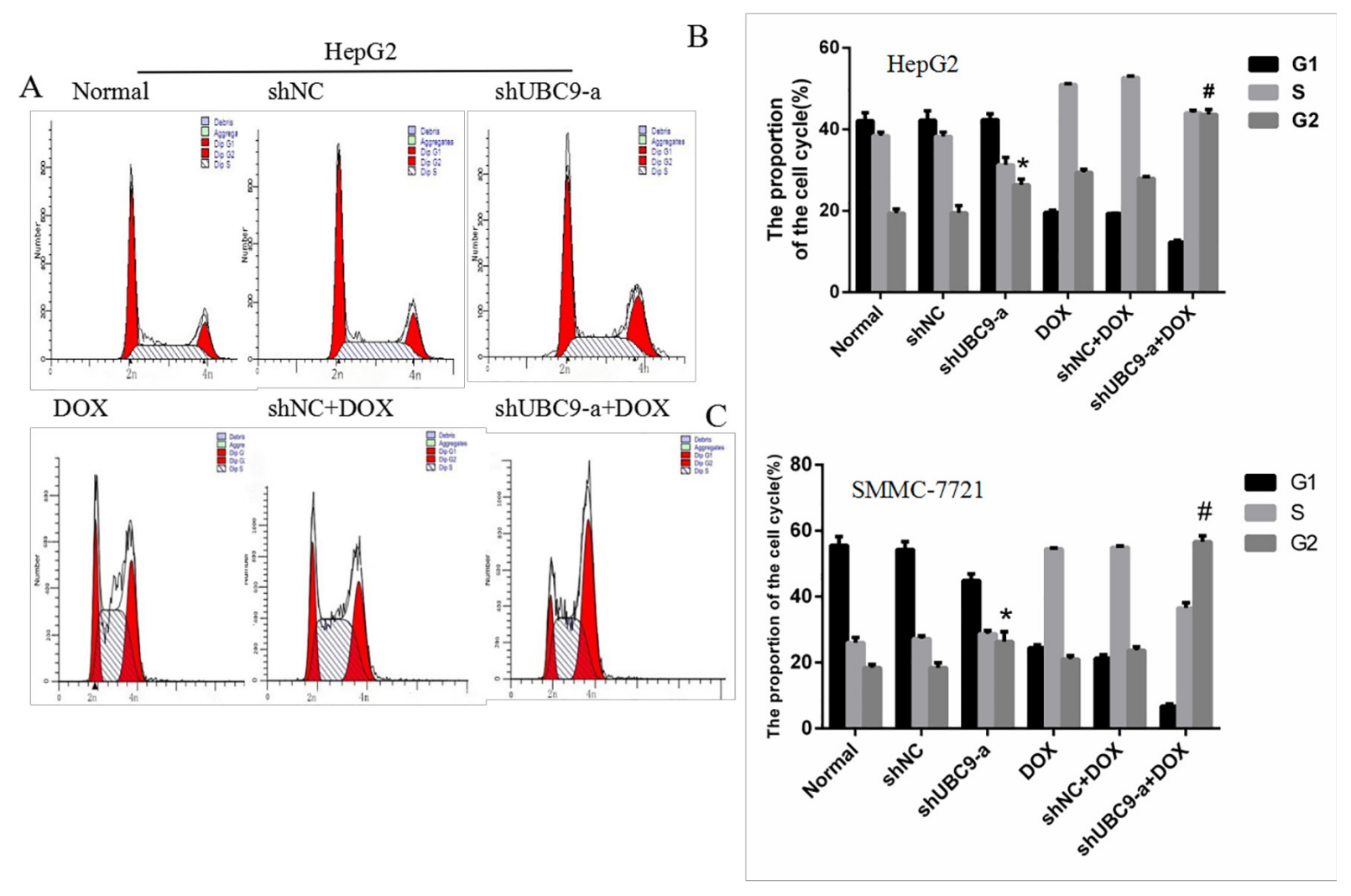

Figure 6: Down-regulation of UBC9 improved the DOX-induced cell cycle arrest of HCC cells. (A) Cell cycle distribution was assessed with the Cell Cycle Analysis Kit. (B and C) HepG2 and SMMC-7721cells with UBC9 shRNA in combination with DOX showed a significantly increased rate in the G2 phase compared to cells in the Normal or NC shRNA Combination with DOX groups $\left({ }^{\sharp} P<0.001\right)$. The shUBC9-a group also showed a significantly increased rate in the G2 phase compared to the Normal or NC shRNA groups $(* P<0.001)$. 
pathways. These findings suggested that the increased sensitivity of HCC cells to doxorubicin induced by down-regulation of UBC9 was achieved by inhibiting the MAPK signaling pathway. The results further showed that inhibition of UBC9 gene expression could increase the sensitivity of HCC cells to doxorubicin.

In summary, we demonstrated that UBC9 was overexpressed in $\mathrm{HCC}$ and that its expression was correlated with clinical outcomes. Our results also showed that down-regulation of UBC9 increased the sensitivity to DOX in hepatocellular carcinoma cells. This phenomenon occurs due to decreased expression of Bcl-2 and Bcl-xl and increased expression of cleaved-Caspase3, which resulted in DOX-induced apoptosis. Furthermore, inhibition of the ERK1/2 and P38 MAPK pathways by down-regulation of UBC9 could increase the response to DOX in HCC cells. These results suggest that UBC9 may be a potential candidate for a chemosensitizer in the treatment of $\mathrm{HCC}$ and imply that UBC9 down-regulation might serve as a therapeutic target for hepatocellular carcinoma.

\section{MATERIALS AND METHODS}

\section{Samples}

Human HCC specimens were collected from 103 patients who received an $\mathrm{HCC}$ resection at the Second

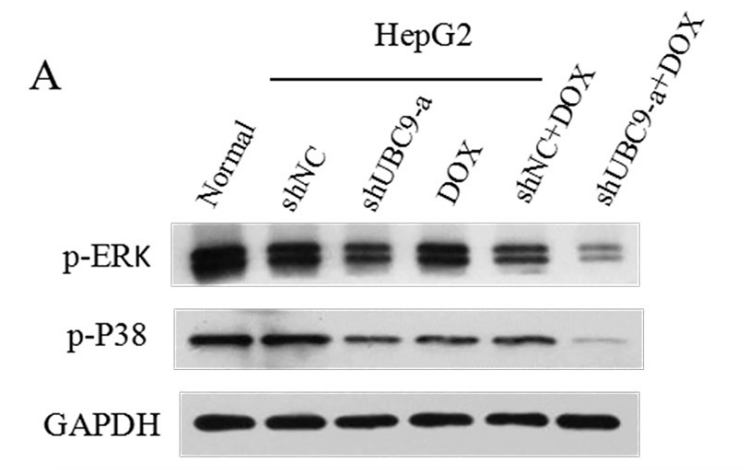

B

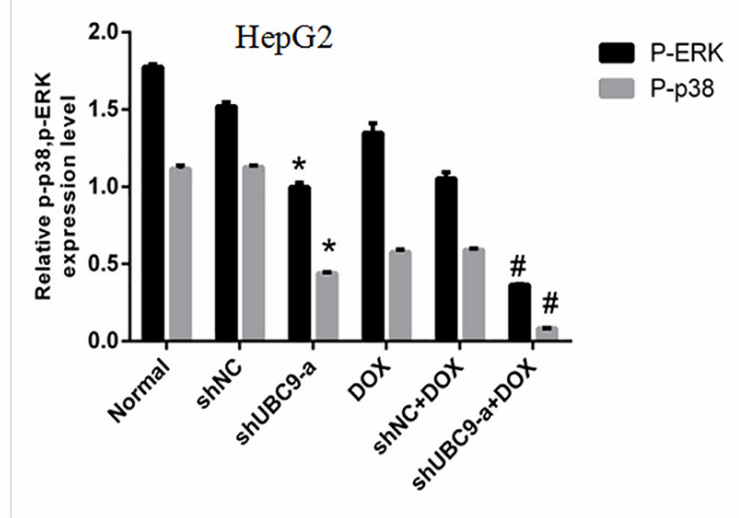

Affiliated Hospital of Nanchang University between January 2014 and December 2015. Informed consent was obtained from each patient, and the study protocol was approved by the Ethics Committee of the Second Affiliated Hospital of Nanchang University.

\section{Materials}

HepG2 and SMMC-7721 cells were purchased from the Cell Bank of the Chinese Academy of Sciences (Shanghai, China). Lipofectamine 2000 Reagent was purchased from Transgen Biotech (Beijing, China). DOX was purchased from Nanjing Keygen Biotech. Anti-Bcl-2, anti-Bax, cleaved-Caspase 3, anti-Caspase 3 anti-GAPDH were obtained from Proteintech (Wuhan, China). Anti-p38, anti-p-p38, anti-ERK1/2 and anti-p-ERK1/2 were obtained from Cell Signaling (Boston, MA, USA). Anti-UBC9, anti-Bcl-xl, anti-JNK and anti-p-JNK were obtained from Abcam (Boston, MA, USA). Cell Counting Kit-8 (CCK8) was purchased from Bytotime Company (Nantong, Jiangsu Province, China). The Annexin V/FITC kit was purchased from BD (BioSciences, USA). The Chemiluminescence (ECL) assay kit was purchased from Amersham (Arlington Heights, USA). The mouse anti-GAPDH polyclonal antibody $(1: 1,0000)$ (Proteintech, Wuhan, China), antirabbit $(1: 10,000)$ and anti-mouse $(1: 10,000)$ IgGs were purchased from Proteintech (Wuhan, China).
C

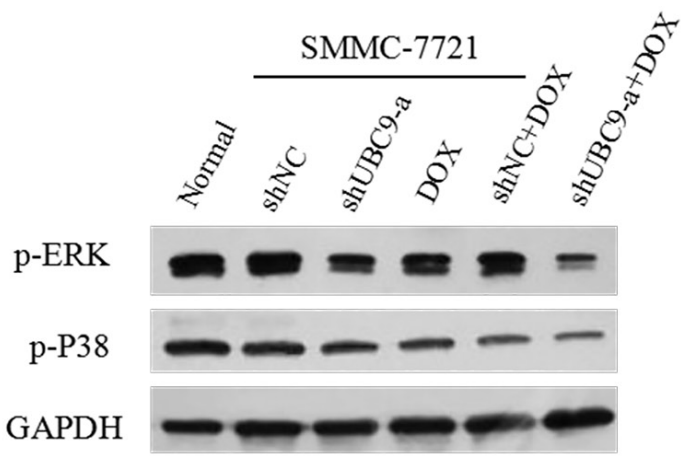

$\mathrm{D}$

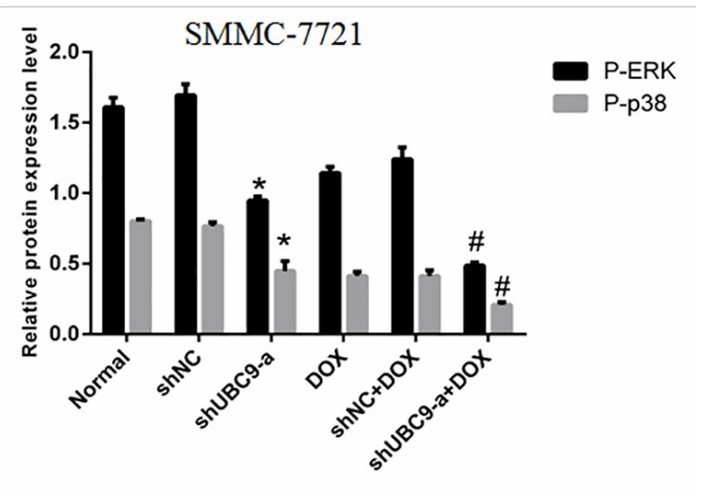

Figure 7: UBC9 knockdown influenced the expression and activation of multiple downstream genes. (A and C) The expression of p-ERK and p-p38was evaluated by Western blot with GAPDH as a loading control. (B and D) Graph of the relative ratios of p-ERK and p-P38 protein to GAPDH in each group. ${ }^{*} P<0.01$ vs NC shRNA transfected cells, ${ }^{\#} P<0.001$ vs the other groups, $n=6$. 


\section{Cell cultures and transfections}

HCC cells were cultured in Dulbecco's modified Eagle's medium (DMEM, Solarbio, Shanghai, China) supplemented with penicillin $(100 \mathrm{U} / \mathrm{mL})$, streptomycin $(0.1 \mathrm{mg} / \mathrm{ml})$, and $10 \%$ fetal bovine serum (Gibco, Grand Island, NY, USA). Cells were grown at $37^{\circ} \mathrm{C}$ in a $95 \%$ air and $5 \% \mathrm{CO}_{2}$ atmosphere. HepG2 cells were transfected with either plasmids expressing UBC9 shRNA or empty vector plasmids using a Lipofectamine 2000 transfection reagent according to the manufacturer's instructions. The plasmid-transfected HCC cells were cultivated at $37^{\circ} \mathrm{C}$ for 24 hours. The transfected cells were divided into six experimental groups: Normal, shNC, shUBC9-a, DOX, shNC+DOX, sh-UBC9-a+DOX. After 24 hours, the transfected cells were collected for analysis of mRNA and protein expression. shUBC9-a: 5'-GGAGGAAAGACCACCCATTTG-3'; shUBC9-b:5'GCACGATGAACCTCATG AACT-3'; shUBC9-c:5'GCAGGCCTACACGATTTTAC-3'.

\section{Real-time quantitative polymerase chain reaction (qRT-PCR)}

Total RNA was extracted using TRIzol (Invitrogen), and cDNA synthesis was performed using the Prime-Script RT reagent Kit (Takara, Japan). Quantitative-PCR was performed using the SYBR Premix Ex Taq TMII (Takara) on an Applied Biosystems 7300 Real-Time PCR System (ABI, USA). The UBC9 primer sequence came from PrimerBank (http://pga.mgh.harvard.edu/primerbank/). Oligomer primers were designed for the following genes: UBC9 (Sense: 5-CAG GAA AGA AAG GGA CTC-3; Antisense: 5-TTC GGG TGA AAT AAT GG-3) and GAPDH: (Sense: 5-GCA TCC TGC ACC ACC AAC T-3; Antisense: 5-GCA GTG ATG GCA TGG ACT GT-3). Each reaction had a total volume of $20 \mu \mathrm{l}$, including $12.5 \mu \mathrm{l}$ of SYBR Green master mix, $200 \mathrm{nmol}$ of each forward and reverse primer, $1 \mu \mathrm{l}$ of cDNA, and $7 \mu \mathrm{l}$ of $\mathrm{ddH}_{2} \mathrm{O}$. The cycling conditions included an initial denaturation step of 10 minutes at $94^{\circ} \mathrm{C}$, followed by 40 cycles of 15 seconds at $95^{\circ} \mathrm{C}$, one minute at $55^{\circ} \mathrm{C}$ and one minute at $60^{\circ} \mathrm{C}$.

\section{Western blot}

The six experimental groups were removed from the incubator. The cells were washed with ice-cold PBS twice andharvested. Then, cell lysates were prepared using RIPA buffer supplemented with protease inhibitors (100 mM Tris, pH7.4, $150 \mathrm{mM} \mathrm{NaCl}, 5 \mathrm{mM}$ EDTA, $1 \%$ Triton $\mathrm{X}-100,1 \%$ deoxycholate acid, $0.1 \%$ SDS, $2 \mathrm{mM}$ phenylmethylsulfonylfluoride, $1 \mathrm{mM}$ sodium orthovanadate, $2 \mathrm{mM}$ DTT, $2 \mathrm{mM}$ leupeptin, $2 \mathrm{mM}$ pepstatin). The protein concentrations were determined using the BCA protein assay (Thermo Fisher Scientific, Rockford, USA). Then, $10 \mu \mathrm{l}$ of each sample was separated by SDS-polyacrylamide gel electrophoresis and transferred to a PVDF membrane ( 0.22 micrometer, Bio-Rad) and then blocked with 5\% skim milk at room temperature. The membrane was incubated with primary antibodies overnight at $4^{\circ} \mathrm{C}$. The membrane was washed in TBST three times (10 min each time). Then, the PVDF membrane was incubated with the appropriate secondary antibody at room temperature for $2 \mathrm{~h}$. The PVDF membrane was washed in TBST three times (10 min each time). The proteins were visualized using the Amersham $^{\text {TM }}$ ECL Plus Western Blotting Detection System (GE Healthcare, UK).

\section{Cell viability assay}

To evaluate the proliferation effect of UBC9 in HCC cells, shUBC9-a and shNC stable cells were digested and counted, and $1 \times 10^{4}$ cells in $100 \mu \mathrm{l}$ medium were seeded in 96-well plates. After a $24 \mathrm{~h}$ incubation, the cultured cells were adherent. Different concentrations of $\operatorname{DOX}(0,0.1,0.2,0.4,0.5,0.8$ and $1.6 \mu \mathrm{g} / \mathrm{ml})$ were added to the medium. After incubating the cells at $37^{\circ} \mathrm{C}(5 \%$ $\mathrm{CO}_{2}$ ) for $24 \mathrm{~h}, 10 \mu \mathrm{l}$ of CCK-8 cells (Bytotime, Jiangsu, China) were added to the medium. After the cells were incubated for another $2 \mathrm{~h}$ at $37^{\circ} \mathrm{C}\left(5 \% \mathrm{CO}_{2}\right)$, we measured the opticaldensity (OD) at $450 \mathrm{~nm}$ on a microplate reader $($ Bio-Rad, California, USA $)$. The relative inhibition rate $=$ (OD of control group - OD of drug group)/OD of control group $\times 100 \%$. We used SPSS 18.0 to calculate the half maximal inhibitory concentration (IC50).

\section{Apoptosis assay by AnnexinV-FITC/PI staining}

Cells $\left(5 \times 10^{5}\right)$ were seeded in 6-well plates. After the cells were transfected, $0.3 \mu \mathrm{g} / \mathrm{ml}$ DOX was added to the medium, and the cells were incubated for $24 \mathrm{~h}$. We harvested the adherent cells, washed the cells twice with cold PBS and then resuspended the cells in $1 \times$ Binding Buffer at a concentration of $1 \times 10^{6}$ cells $/ \mathrm{ml}$. Then $100 \mu \mathrm{l}$ of the solution was transferred to a $5 \mathrm{ml}$ culture tube. Next, $5 \mu \mathrm{l}$ of AnnexinV-PE and $5 \mu \mathrm{l}$ of PI were added (BD BioSciences, USA). The cells were gently vortexed and incubated for $15 \mathrm{~min}$ at $\mathrm{RT}\left(25^{\circ} \mathrm{C}\right)$ in the dark. Finally, we added $400 \mu \mathrm{l}$ of $1 \times$ binding buffer to each tubeaccording to the manufacturer's instructions. The stained cells were examined with FACSCalibur flow cytometry.

\section{Cell-cycle phase distribution assay}

Cells $\left(5 \times 10^{5}\right)$ were seeded in 6-well plates after transfection, and then, $0.3 \mu \mathrm{g} / \mathrm{ml}$ DOX was added to the medium. After incubation for $48 \mathrm{~h}$, the adherent cells were collected and washed twice with cold PBS. Then, the cells were fixed in ice cold $70 \%$ ethanol. The cell cycle distribution was analyzed using the Cell Cycle Analysis 
Kit (MultiSciences, China). The percentage of cells in different phases of each cell cycle was sorted using a ModFit 5.2 computer program.

\section{Immunohistochemistry}

The level of UBC9 in paraffin-embedded tissue sections was detected with immunohistochemical staining. A goat monoclonal antibody was used as the primary antibody. Paraffin-embedded tissues were pretreated at $65^{\circ} \mathrm{C}$ for $2 \mathrm{~h}$, followed by deparaffinization using standard procedures. Antigen retrieval was carried out with an antigen retrieval solution $(10 \mathrm{mmol} / \mathrm{L}$ Tris, $1 \mathrm{mmol} / \mathrm{L}$ EDTA, Ph 9.0) before $2 \%$ sheep serum was added. Then, the slides were incubated with the antibody for UBC9 (ab21193, Abcam) (1:200 dilution)at $4{ }^{\circ} \mathrm{C}$ overnight. Next, the slides were labeled with EnVision HRP kits (DAKO) at room temperature for 30 minutes, incubated with $\mathrm{DAB}$ substrate liquid (DAKO), and counterstained with Mayers hematoxylin(DAKO). All of the sections were observed and photographed with a light microscope using a DP70 CCD system (Olympus Corp.).

\section{Statistics}

All data were analyzed using SPSS 18.0. The results are presented as the means \pm SD from three independent experiments. The differences between the groups were analyzed by the Student $t$ test when two groups were compared or by one-way ANOVA when more than two groups were compared. The correlations between the UBC9 expression levels and clinical pathological variables were analyzed using Pearson's Chi-squared test. The test results were considered significant at $P<0.05$.

\section{ACKNOWLEDGMENTS AND FUNDING}

We thank all teachers in the Key Laboratory of Molecular Center in Second Affiliated Hospital of Nanchang University for their technical assistance. We also thank Elsevier's English Language Editing service for editing the manuscript. This work was supported by grants from the National Natural Science Foundation of China (No. 81260360 and No.91029720 to GUO).

\section{CONFLICTS OF INTEREST}

The authors declare that they have no conflicts of interest.

\section{REFERENCES}

1. Ferlay J, Soerjomataram I, Dikshit R, Eser S, Mathers C, Rebelo M, Parkin DM, Forman D, Bray F. Cancer incidence and mortality worldwide: sources, methods and major patterns in GLOBOCAN 2012. Int J Cancer. 2015; 136:E359-E386.

2. Chen W, Zheng R, Baade PD, Zhang S, Zeng H, Bray F, Jemal A, Yu XQ, He J. Cancer statistics in China, 2015. CA Cancer J Clin. 2016; 66:115-132.

3. Maluccio M, Covey A. Recent progress in understanding, diagnosing, and treating hepatocellular carcinoma. CA Cancer J Clin. 2012; 62:394-399.

4. Ciuleanu T, Bazin I, Lungulescu D, Miron L, Bondarenko I, Deptala A, Rodriguez-Torres M, Giantonio B, Fox NL, Wissel P, Egger J, Ding M, Kalyani RN, et al. A randomized, double-blind, placebo-controlled phase II study to assess the efficacy and safety of mapatumumab with sorafenib in patients with advanced hepatocellular carcinoma. Ann Oncol. 2016; 27:680-687.

5. Llovet JM, Ricci S, Mazzaferro V, Hilgard P, Gane E, Blanc JF, de Oliveira AC, Santoro A, Raoul JL, Forner A, Schwartz M, Porta C, Zeuzem S, et al. Sorafenib in advanced hepatocellular carcinoma. N Engl J Med. 2008; 359:378-390.

6. Cheng AL, Kang YK, Chen Z, Tsao CJ, Qin S, Kim JS, Luo R, Feng J, Ye S, Yang TS, Xu J, Sun Y, Liang H, et al. Efficacy and safety of sorafenib in patients in the AsiaPacific region with advanced hepatocellular carcinoma: a phase III randomised, double-blind, placebo-controlled trial. Lancet Oncol. 2009; 10:25-34.

7. Vincenzi B, Santini D, Russo A, Addeo R, Giuliani F, Montella L, Rizzo S, Venditti O, Frezza AM, Caraglia M, Colucci G, Del Prete S, Tonini G. Early skin toxicity as a predictive factor for tumor control in hepatocellular carcinoma patients treated with sorafenib. Oncologist. 2010; 15:85-92.

8. Cho JY, Paik YH, Lim HY, Kim YG, Lim HK, Min YW, Gwak GY, Choi MS, Lee JH, Koh KC, Paik SW, Yoo BC. Clinical parameters predictive of outcomes in sorafenibtreated patients with advanced hepatocellular carcinoma. Liver Int. 2013; 33:950-957.

9. Lencioni R, Kudo M, Ye SL, Bronowicki JP, Chen XP, Dagher L, Furuse J, Geschwind JF, de Guevara LL, Papandreou C, Takayama T, Yoon SK, Nakajima K, et al. GIDEON (Global Investigation of therapeutic DEcisions in hepatocellular carcinoma and of its treatment with sorafenib): second interim analysis. Int J Clin Pract. 2014; 68:609-617.

10. Muller S, Hoege C, Pyrowolakis G, Jentsch S. SUMO, ubiquitin's mysterious cousin. Nat Rev Mol Cell Biol. 2001; 2:202-210.

11. Zhou F, Xue Y, Lu H, Chen G, Yao X. A genome-wide analysis of sumoylation-related biological processes and functions in human nucleus. Febs Lett. 2005; 579: 3369-3375.

12. Hochstrasser M. Origin and function of ubiquitin-like proteins. Nature. 2009; 458:422-429. 
13. Desterro JM, Thomson J, Hay RT. Ubch9 conjugates SUMO but not ubiquitin. Febs Lett. 1997; 417:297-300.

14. Hayashi T, Seki M, Maeda D, Wang W, Kawabe Y, Seki T, Saitoh H, Fukagawa T, Yagi H, Enomoto T. Ubc9 is essential for viability of higher eukaryotic cells. Exp Cell Res. 2002; 280:212-221.

15. Johnson ES, Blobel G. Ubc9p is the conjugating enzyme for the ubiquitin-like protein Smt3p. J Biol Chem. 1997; 272:26799-26802.

16. Seeler JS, Dejean A. Nuclear and unclear functions of SUMO. Nat Rev Mol Cell Biol. 2003; 4:690-699.

17. Gill G. SUMO and ubiquitin in the nucleus: different functions, similar mechanisms? Genes Dev. 2004; 18: 2046-2059.

18. Johnson ES. Protein modification by SUMO. Annu Rev Biochem. 2004; 73:355-382.

19. Zhao J. Sumoylation regulates diverse biological processes. Cell Mol Life Sci. 2007; 64:3017-3033.

20. Li YJ, Stark JM, Chen DJ, Ann DK, Chen Y. Role of SUMO:SIM-mediated protein-protein interaction in nonhomologous end joining. Oncogene. 2010; 29:3509-3518.

21. Kang JS, Saunier EF, Akhurst RJ, Derynck R. The type I TGF-beta receptor is covalently modified and regulated by sumoylation. Nat Cell Biol. 2008; 10:654-664.

22. Desterro JM, Rodriguez MS, Hay RT. SUMO-1 modification of IkappaBalpha inhibits NF-kappaB activation. Mol Cell. 1998; 2:233-239.

23. Yang SH, Sharrocks AD. MAP Kinase: SUMO pathway interactions. Methods Mol Biol. 2010; 661:343-367.

24. Besnard A, Galan-Rodriguez B, Vanhoutte P, Caboche J. Elk-1 a transcription factor with multiple facets in the brain. Front Neuro sci. 2011; 5:35.

25. Al-Khodairy F, Enoch T, Hagan IM, Carr AM. The Schizosaccharomyces pombe hus5 gene encodes an ubiquitin conjugating enzyme required for normal mitosis. J Cell Sci. 1995; 108:475-486.

26. Seufert W, Futcher B, Jentsch S. Role of an ubiquityconjugating enzyme in degradation of S- and M-phase cyclins. Nature. 1995; 373:78-81.

27. Guo Y, Yang MC, Weissler JC, Yang YS. Modulation of PLAGL2 transactivation activity by Ubc9 co-activation not SUMOylation. Biochem Biophys Res Commun. 2008; 374:570-575.

28. Kaul S, Blackford JJ, Cho S, Simons SJ. Ubc9 is a novel modulator of the induction properties of glucocorticoid receptors. J Biol Chem. 2002; 277:12541-12549.

30. Kurtzman AL, Schechter N. Ubc9 interacts with a nuclear localization signal and mediates nuclear localization of the paired-like homeobox protein Vsx-1 independent of SUMO-1 modification. PNAS. 2001; 98:5602-5607.

31. $\mathrm{Lu} \mathrm{Z,} \mathrm{Wu} \mathrm{H,} \mathrm{Mo} \mathrm{YY.} \mathrm{Regulation} \mathrm{of} \mathrm{bcl-2} \mathrm{expression} \mathrm{by}$ Ubc9. Exp Cell Res. 2006; 312:1865-1875.
32. Mo YY, Yu Y, Ee PL, Beck WT. Overexpression of a dominant-negative mutant Ubc9 is associated with increased sensitivity to anticancer drugs. Cancer Res. 2004; 64:2793-2798.

33. Jacquiau HR, van Waardenburg RC, Reid RJ, Woo MH, Guo H, Johnson ES, Bjornsti MA. Defects in SUMO (small ubiquitin-related modifier) conjugation and deconjugation alter cell sensitivity to DNA topoisomerase I-induced DNA damage. J Biol Chem. 2005; 280:23566-23575.

34. Mizutani H, Tada-Oikawa S, Hiraku Y, Kojima M, Kawanishi S. Mechanism of apoptosis induced by doxorubicin through the generation of hydrogen peroxide. Life Sci. 2005; 76:1439-1453.

35. Melchior F. SUMO — nonclassical ubiquitin. Annu Rev Cell Dev Biol. 2000; 16:591-626.

36. Potts PR, Yu H. The SMC5/6 complex maintains telomere length in ALT cancer cells through SUMOylation of telomere-binding proteins. Nat Strut Mol Biol. 2007; 14:581-590.

37. De Lange T. Shelterin: the protein complex that shapes and safeguards human telomeres. Genes Dev. 2005; 19: 2100-2110.

38. Qin Y, Bao H, Pan Y, Yin M, Liu Y, Wu S, Li H. SUMOylation alterations are associated with multidrug resistance in hepatocellular carcinoma. Mol Med Rep. 2014; 9:877-881.

39. Ronen O, Malone JP, Kay P, Bivens C, Hall K, Paruchuri LP, Mo YY, Robbins KT, Ran S. Expression of a novel marker, Ubc9, in squamous cell carcinoma of the head and neck. Head Neck. 2009; 31:845-855.

40. Dunnebier T, Bermejo JL, Haas S, Fischer HP, Pierl CB, Justenhoven C, Brauch H, Baisch C, Gilbert M, Harth V, Spickenheuer A, Rabstein S, Pesch B, et al. Common variants in the UBC9 gene encoding the SUMO-conjugating enzyme are associated with breast tumor grade. Int J Cancer. 2009; 125:596-602.

41. Driscoll JJ, Pelluru D, Lefkimmiatis K, Fulciniti M, Prabhala RH, Greipp PR, Barlogie B, Tai YT, Anderson KC, Shaughnessy JJ, Annunziata CM, Munshi NC. The sumoylation pathway is dysregulated in multiple myeloma and is associated with adverse patient outcome. Blood. 2010; 115:2827-2834.

42. Han JY, Lee GK, Yoo SY, Yoon SJ, Cho EY, Kim HT, Lee JS. Association of SUMO1 and UBC9 genotypes with tumor response in non-small-cell lung cancer treated with irinotecan-based chemotherapy. Pharmacogenomics J. 2010; 10:86-93.

43. Moschos SJ, Smith AP, Mandic M, Athanassiou C, WatsonHurst K, Jukic DM, Edington HD, Kirkwood JM, Becker D. SAGE and antibody array analysis of melanoma-infiltrated lymph nodes: identification of Ubc9 as an important molecule in advanced-stage melanomas. Oncogene. 2007; 26:4216-4225. 
44. Chen SF, Gong C, Luo M, Yao HR, Zeng YJ, Su FX. Ubc9 expression predicts chemoresistance in breast cancer. Chin J Cancer. 2011; 30:638-644.

45. Lei XY, Zhong M, Feng LF, Zhu BY, Tang SS, Liao DF. siRNA-mediated Bcl-2 and Bcl-xl gene silencing sensitizes human hepatoblastoma cells to chemotherapeutic drugs. Clin Exp Pharmacol Physiol. 2007; 34:450-456.

46. Fan M, Chambers TC. Role of mitogen-activated protein kinases in the response of tumor cells to chemotherapy. Drug Resist Updat. 2001; 4:253-267.

47. Ghobrial IM, Witzig TE, Adjei AA. Targeting apoptosis pathways in cancer therapy. CA Cancer J Clin. 2005; 55:178-194.

48. Lei XY, Zhong M, Feng LF, Zhu BY, Tang SS, Liao DF. siRNA-mediated Bcl-2 and Bcl-xl gene silencing sensitizes human hepatoblastoma cells to chemotherapeutic drugs. Clin Exp Pharmacol Physiol. 2007; 34:450-456.

49. Solhaug A, Refsnes M, Lag M, Schwarze PE, Husoy T, Holme JA. Polycyclic aromatic hydrocarbons induce both apoptotic and anti-apoptotic signals in Hepa1c1c7 cells. Carcinogenesis. 2004; 25:809-819.

50. Gao C, Huang W, Kanasaki K, Xu Y. The role of ubiquitination and sumoylation in diabetic nephropathy. Biomed Res Int. 2014; 2014:160692.

51. Wang Y, Abu IA, Ayalew M, Suntay K. Sumoylation of transcription factor Tec1 regulates signaling of mitogenactivated protein kinase pathways in yeast. Plos One. 2009; 4:e7456.
52. Kubota Y, O'Grady P, Saito H, Takekawa M. Oncogenic Ras abrogates MEK SUMOylation that suppresses the ERK pathway and cell transformation. Nat Cell Biol. 2011; 13:282-291.

53. Yang SH, Sharrocks AD. MAP Kinase: SUMO pathway interactions. Methods Mol Biol. 2010; 661:343-367.

54. Peti W, Page R. Molecular basis of MAP kinase regulation. Protein Sci. 2013; 22:1698-1710.

55. Turjanski AG, Vaque JP, Gutkind JS. MAP kinases and the control of nuclear events. Oncogene. 2007; 26:3240-3253.

56. McCubrey JA, Steelman LS, Franklin RA, Abrams SL, Chappell WH, Wong EW, Lehmann BD, Terrian DM, Basecke J, Stivala F, Libra M, Evangelisti C, Martelli AM. Targeting the RAF/MEK/ERK, PI3K/AKT and p53 pathways in hematopoietic drug resistance. Adv Enzyme Regul. 2007; 47:64-103.

57. Mohana-Kumaran N, Hill DS, Allen JD, Haass NK. Targeting the intrinsic apoptosis pathway as a strategy for melanoma therapy. Pigment Cell Melanoma Res. 2014; 27:525-539.

58. Mansouri A, Ridgway LD, Korapati AL, Zhang Q, Tian L, Wang Y, Siddik ZH, Mills GB, Claret FX. Sustained activation of $\mathrm{JNK} / \mathrm{p} 38$ MAPK pathways in response to cisplatin leads to Fas ligand induction and cell death in ovarian carcinoma cells. J Biol Chem. 2003; 278: 19245-19256. 